\title{
A Simple and Green Analytical Method for the Determination of Formaldehyde
}

\author{
Fabrícia Gasparini, Patrícia L. Weinert, Liliane S. Lima, Leonardo Pezza and Helena R. Pezza* \\ Instituto de Química, Universidade Estadual Paulista, CP 355, 14801-970 Araraquara-SP, Brazil
}

\begin{abstract}
No presente trabalho foi investigado o desenvolvimento de um método espectrofotométrico limpo para a determinação de formaldeído em amostras comerciais. A substituição de reagentes altamente perigosos foi explorada, de modo a atender aos princípios estabelecidos pela química verde. O método proposto baseou-se na reação entre formaldeído e ácido cromotrópico na presença de sulfato de magnésio, produzindo um complexo estável $\mathrm{Mg}^{2+} /$ ciclotetracromotropileno $\left(\lambda_{\max }=535 \mathrm{~nm}\right)$. Não há relatos na literatura sobre a utilização da reação supramencionada na determinação de formaldeído. As condições experimentais foram otimizadas, aplicando-se a metodologia de superfície de resposta. A lei de Lambert-Beer é obedecida na faixa de concentração de 3 a $11 \mathrm{mg} \mathrm{L}^{-1}$ de formaldeído, com coeficiente de correlação de 0,999 . O método proposto para a determinação de formaldeído foi aplicado em amostras comerciais de desinfetantes e defrizantes capilares. Os resultados compararam-se favoravelmente aos obtidos pelo método oficial, demonstrando exatidão e precisão satisfatórias.
\end{abstract}

A green spectrophotometric analytical method for determination of formaldehyde in commercial samples was designed and investigated. Replacement of hazardous reagents was explored to attain the clean chemistry standards. The method is based on formaldehyde reaction with chromotropic acid in the presence of magnesium sulphate producing a stable complex $\mathrm{Mg}^{2+} /$ cyclotetrachromotropylene $\left(\lambda_{\max }=535 \mathrm{~nm}\right)$. To the best of our knowledge, there are no reports on the use of the above mentioned reaction for this determination. The experimental conditions were optimized by the response surface methodologies. Beer's Law is obeyed in a concentration range of 3 to $11 \mathrm{mg} \mathrm{L}^{-1}$ of formaldehyde with a correlation coefficient of 0.999 . The proposed method was applied for the determination of formaldehyde in commercial disinfectants and deffrizing hair products. The results were favorably compared with those of the official method, with good accuracy and precision.

Keywords: formaldehyde, $\mathrm{Mg}^{2+} /$ cyclotetrachromotropylene, disinfectants, deffrizing products, green analytical chemistry

\section{Introduction}

Formaldehyde $\left(\mathrm{CH}_{2} \mathrm{O}\right.$, methanal, formic aldehyde, oxomethane $)^{1}$ is the most common aldehyde in the environment and its application covers a wide range. Formaldehyde appears as free formaldehyde, formaldehyde donated from formaldehyde-releasing preservatives and as formaldehyde resins. Free formaldehyde and formaldehyde-releasing preservatives are used not only as preservatives in household products (detergents, topical medications and cosmetics ingredient), but also in industrial products (paints, cutting fluids, lacquers and disinfectants), as well, as in a large number of miscellaneous applications. ${ }^{2}$

*e-mail: hrpezza@iq.unesp.br
Formaldehyde is considered one of the most significant industrial hazards and air pollutants, ${ }^{3}$ and its toxicity to man and to animals has been reported. ${ }^{2,3}$ The International Agency for Research on Cancer has concluded that formaldehyde is a potential carcinogen for animals and that there is a limited evidence for its carcinogenicity in human beings. ${ }^{4}$

Due to the large formaldehyde production, usage and the possible exposure-related health effects, there is a tendency to restrict and regulate its use in consumer products. Formaldehyde-releasing preservatives have replaced formaldehyde in most cosmetic and industrial products, as they are less frequent sensitizers. ${ }^{5}$ On the other hand, the illicit addition of formaldehyde in defrizzing products to hair smoothing is sometimes a very serious problem in Brazil. ${ }^{6}$ Some people are hypersensitive to formaldehyde 
and even a slight exposure, may lead to severe reaction in such instances. ${ }^{6}$

In order to restrict and regulate the use of formaldehyde in consumer products with regard to its toxicity and antiseptic activity, suitable analytical methods are required. Various methods are available for its determination. ${ }^{7}$ Along with the optical techniques, simple methods based on spectrophotometry have become an accepted analytical tool for this determination.

The most widely used method for the determination of formaldehyde is based on spectrophotometry ${ }^{8-13}$ because of its relative low-cost, simplicity and sensitivity. Spectrophotometric chromotropic acid (CA) method has been recommended by the National Institute for Occupational Safety and Health - NIOSH ${ }^{11,12}$ in its P\&CAM 125, 235 and 3500 reference methods. In the CA method the spectrophotometric measurements are highly selective and other aldehydes do not interfere according to Georghiou and Ho. ${ }^{13}$ The major drawback presented by the NIOSH method has been the use of concentrated $\mathrm{H}_{2} \mathrm{SO}_{4}$, which is potentially hazardous and corrosive, and the requirement of heating the resulting solution for about one hour in a steam bath $\left(100^{\circ} \mathrm{C}\right)$, making its utilization less attractive in routine analysis. In previous studies, modifications in the NIOSH procedure were described. ${ }^{14,15}$ However, these modifications also require a large volume of concentrated and corrosive acids.

The majority of the analytical methods employed for the determination of formaldehyde uses corrosive or toxic reagents and generates chemical wastes, laying outside of the standards of green analytical chemistry. ${ }^{16}$ The aim of green analytical chemistry is to use analytical procedures that generate less hazardous waste, which may be achieved by developing new analytical methodologies or simply modifying an old method to incorporate procedures that use less hazardous chemicals. ${ }^{17}$

Nowadays, toxicity and danger of the reagents used and the waste produced in the development of new analytical procedures are as important as any other analytical feature. ${ }^{17}$ Hence, there is a great need to develop methods which are less harmful to humans and to the environment, according to the twelve principles stated by the green chemistry. ${ }^{18}$

In order to develop such methodologies, i.e., eliminating the use of corrosive concentrated acids, a new spectrophotometric method for formaldehyde determination is proposed. The method uses the reaction of formaldehyde with chromotropic acid in the presence of magnesium sulphate, producing a coloured complex with maximum absorption at $535 \mathrm{~nm}$. To the best of our knowledge, the analytical potentiality of this reaction for formaldehyde determination has not been explored previously. Experimental design methodologies were used to optimize the conditions. This method was successfully applied in the analysis of commercial samples of disinfectants and defrizzing hair products.

\section{Experimental}

\section{Apparatus}

An USB2000 spectrophotometer (Ocean Optics, Dunedin, USA) with $1 \mathrm{~cm}$ matched silica cells was used for all absorbance measurements. Brand (100 to $1000 \mu \mathrm{L}$ ) and Eppendorf (10 to $100 \mu \mathrm{L}$ ) micropipettes were used to measure small volumes.

\section{Materials, reagents and solutions}

High purity deionized water (resistivity $18.2 \mathrm{M} \Omega . \mathrm{cm}$ ) obtained by using a Milli-Q plus system (Millipore Corp., Bedford, MA, USA) and grade 'A' glassware were used throughout.

Formaldehyde stock solution: a $1000 \mathrm{mg} \mathrm{L}^{-1}$ aqueous solution was prepared by dilution of $2.50 \mathrm{~mL}$ of the commercially available analytical-reagent grade formaldehyde solution (37\% Mallinckrodt Co., Xolstoc, Mexico) in a $1000 \mathrm{~mL}$ standard flask, and standardized by AOAC method..$^{13}$ The standard formaldehyde solutions used for calibration graph were freshly prepared by appropriate dilution with water.

Chromotropic acid (disodium salt dihydrate, $\mathrm{C}_{10} \mathrm{H}_{6} \mathrm{O}_{8} \mathrm{~S}_{2} \mathrm{Na}_{2} \cdot 2 \mathrm{H}_{2} \mathrm{O}$, Merck, Germany, $\left.98.5 \%\right)$ : a $5 \%(\mathrm{~m} / \mathrm{v})$ aqueous solution was freshly prepared by dissolving $1.25 \mathrm{~g}$ of the solute with deionized water in a standard $25 \mathrm{~mL}$ flask.

Magnesium sulphate $\left(\mathrm{MgSO}_{4} \cdot 7 \mathrm{H}_{2} \mathrm{O}\right.$, Synth, Brazil, purity grade $98.0-102.0 \%)$ : a $60 \%(\mathrm{~m} / \mathrm{v})$ aqueous solution was prepared, weighing $60.0 \mathrm{~g}$ of the solute and dissolving with deionized water in a standard $100 \mathrm{~mL}$ flask.

\section{Recommended procedure}

A calibration curve was prepared as following: $1.00 \mathrm{~mL}$ of formaldehyde working standard solution (comprising $30-110 \mathrm{~m} \mathrm{~L} \mathrm{~L}^{-1}$ of formaldehyde) was transferred into $25 \mathrm{~mL}$ glass tubes, then $290 \mu \mathrm{L}$ of $5 \%$ CA solution and $3.00 \mathrm{~mL}$ of $60 \% \mathrm{MgSO}_{4}$ solution (under stirring) were added. The tubes were sealed with PTFE tape and heated for $60 \mathrm{~min}$ in a steam bath $\left(100^{\circ} \mathrm{C}\right)$, followed by cooling. The solutions were quantitatively transferred into $10 \mathrm{~mL}$ standard flasks and the volume completed with deionised water. The absorbance measurements were recorded at $535 \mathrm{~nm}$. 


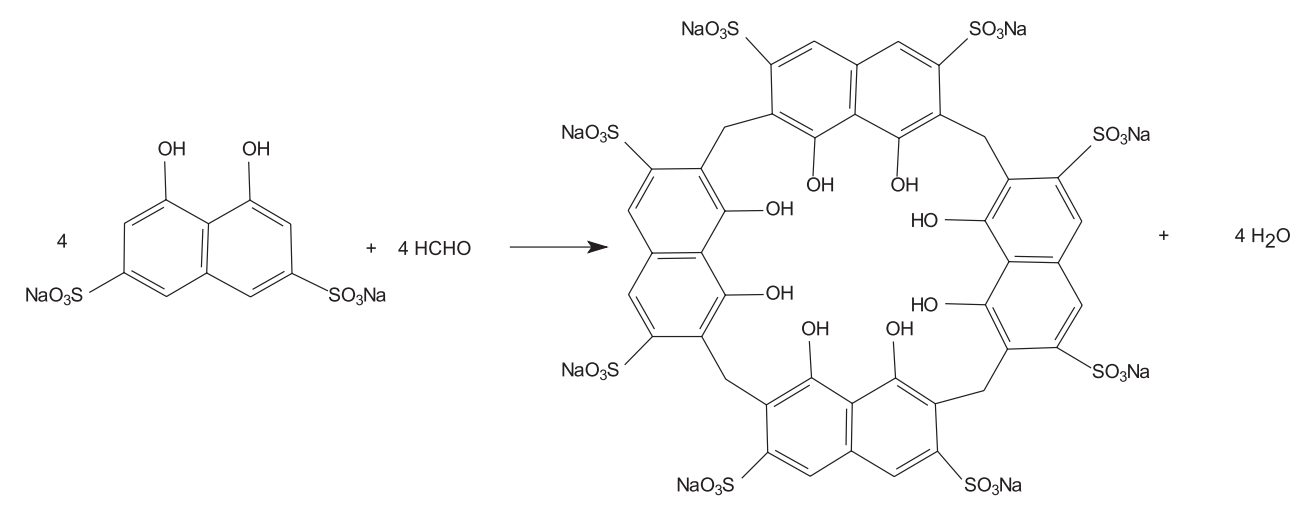

Scheme 1.

\section{Sample preparation and analytical application}

Disinfectants: commercial preparations containing $8.2 \%$ and $4.0 \%(\mathrm{~m} / \mathrm{v})$ of formaldehyde were assayed. A $500 \mu \mathrm{L}$ and $1000 \mu \mathrm{L}$ of each one containing $8.2 \%$ and $4.0 \%(\mathrm{~m} / \mathrm{v})$ of formaldehyde, respectively, were transferred into $100 \mathrm{~mL}$ standard flasks and the volume completed with deionised water. Subsequently, $600 \mu \mathrm{L}$ of these solutions were diluted to $100 \mathrm{~mL}$.

Defrizzing hair products with illicit addition of formaldehyde: $0.500 \mathrm{~g}$ of the each sample was accurately weighed, dissolved with about $20 \mathrm{~mL}$ of deionized water and the volume completed to $100 \mathrm{~mL}$. Then, $5.00 \mathrm{~mL}$ of this solution was diluted to $25 \mathrm{~mL}$ with deionized water. Aliquots of $1.00 \mathrm{~mL}$ of each one of these solutions were taken for analysis, following the described procedure recommended.

\section{Reference method}

In order to compare the results obtained by the proposed method, the basic NIOSH procedure using concentrated $\mathrm{H}_{2} \mathrm{SO}_{4}$ and heating for one hour in a steam bath $\left(100{ }^{\circ} \mathrm{C}\right)$ was followed with modifications as described by Georghiou and Ho. ${ }^{13}$

\section{Results and Discussion}

The reaction of chromotropic acid with formaldehyde has been used in chemical analysis since 1937. The structure of the coloured compound $\left(\lambda_{\max }=580 \mathrm{~nm}\right)$, formed with concentrated $\mathrm{H}_{2} \mathrm{SO}_{4}(96 \%)$ was confirmed in 1989 by Georghiou and Ho. ${ }^{13}$ The literature describes that a completely different compound has been obtained from the reaction (in aqueous solution) between chromotropic acid and an excess of formaldehyde (1:5) if left standing in a stoppered flask for a week. ${ }^{19}$ The resulting macrocyclic compound, named cyclotetrachromotropylene (Scheme 1), is capable of forming complexes in solutions with some metal cations. ${ }^{20}$

Preliminary experiments carried out in our laboratory revealed that, in the presence of $\mathrm{MgSO}_{4} \cdot 7 \mathrm{H}_{2} \mathrm{O}$ solution, a red product has been produced after heating the formaldehyde with an excess of chromotropic acid in a steam bath. In the absence of magnesium sulphate this reaction does not occur. Probably, the oxygen atoms of the cyclo-tetrachromotropylene hydroxyl groups are preorganized for complexation with magnesium, similarly to the calixarenes. ${ }^{21}$

The absorption spectrum of the reaction product (Figure 1) shows that the best analytical wavelength is located at $535 \mathrm{~nm}$. The resulting chromogen is stable for at least $2 \mathrm{~h}$, at room temperature.

Based on these experiments, a new cleaner analytical method was devised, in which the use of concentrated acids

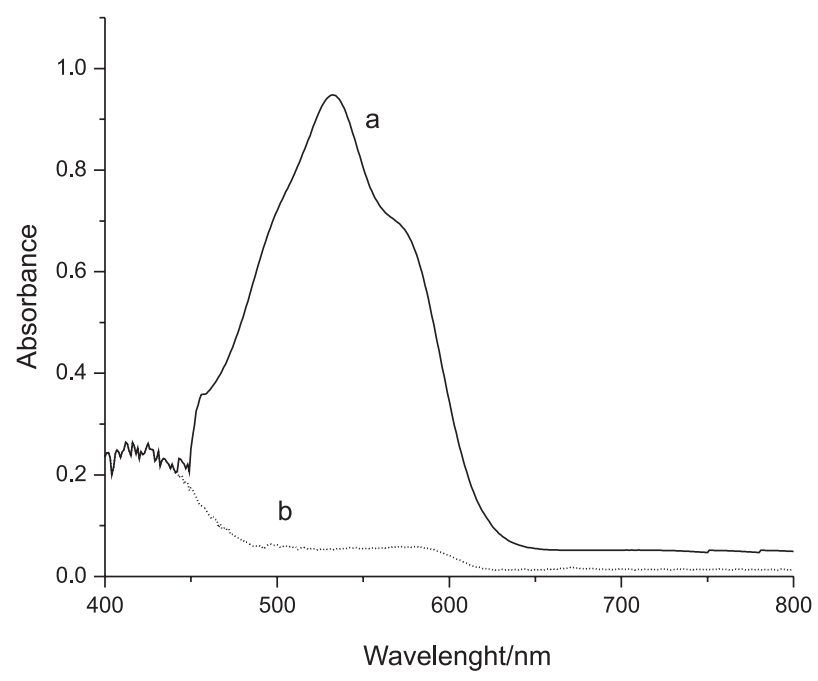

Figure 1. Reaction product (a) and blank (b) absorption spectra. Formaldehyde concentration $=11 \mathrm{mg} \mathrm{L}^{-1} ; \mathrm{b}=1 \mathrm{~cm}$. Measurements taken at $25^{\circ} \mathrm{C}$ after heating, cooling and diluting, as described in the recommended procedure. 
was eliminated and advantageously replaced by magnesium sulphate.

\section{Experimental design}

Investigations were carried out to establish the most favorable conditions for the reaction in order to achieve maximum absorbance response at $535 \mathrm{~nm}$. The variables examined in this study, namely volume of chromotropic acid $5 \%(\mathrm{~m} / \mathrm{v})$, volume of $\mathrm{MgSO}_{4} \cdot 7 \mathrm{H}_{2} \mathrm{O} 60 \%(\mathrm{~m} / \mathrm{v})$ and heating time, were sequentially optimized.

Initially, a full factorial design ${ }^{22}$ was carried out, which allowed simultaneously studying three factors that could have an important effect on the reaction. The factors of interest were volume of chromotropic acid $5 \%(\mathrm{~m} / \mathrm{v})$, volume of $\mathrm{MgSO}_{4} \cdot 7 \mathrm{H}_{2} \mathrm{O} 60 \%(\mathrm{~m} / \mathrm{v})$ and heating time. The two replicates experiments were randomly carried out. It should be mentioned that for all experiments, blanks corresponding to each ones were also carried out.

The factorial design was evaluated using the absorbance intensity as response. The experimental matrix employed with the variables and its levels examined (un-coded and coded) are summarized in Table 1 . In all experiments, the formaldehyde concentration was kept constant. The designs were obtained by using Statistic program, Version 6.0. All experiments were carried out in random order to eliminate environmental variance. The experiments were carried out in duplicate at center points to obtain an estimate of the experimental uncertainty.

As result of the full factorial design, Pareto chart was drawn (Figure 2) in order to visualize the estimated effects of the main factors. Pareto chart gives a graphical

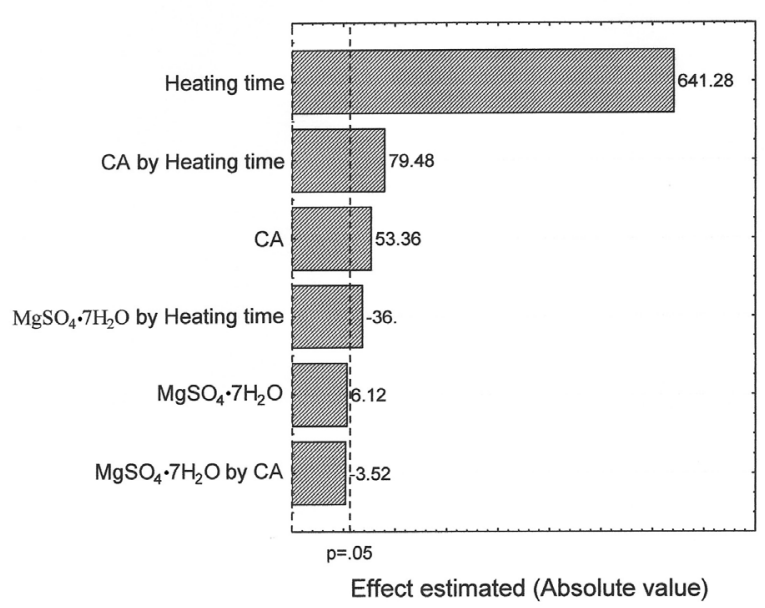

Figure 2. Standardized effects of $5 \% \mathrm{CA}$ volume, $60 \% \mathrm{MgSO}_{4} \cdot 7 \mathrm{H}_{2} \mathrm{O}$ volume and heating time and their interaction effects on the absorbance measurements $(\lambda=535 \mathrm{~nm})$.

presentation for these effects and it allows looking at both the magnitude and the importance of an effect. In this Pareto chart, the length of each bar on the chart is proportional to the absolute value of its associated estimated effect or the standardized effect. The most significant effect corresponds to the factor heating time, which shows a best response when adjusted at positive level $(+1)$. The CA volume and the interactions of $\mathrm{CA}$ with heating time and $\mathrm{MgSO}_{4} \cdot 7 \mathrm{H}_{2} \mathrm{O}$ with heating time have also been an effect on the absorbance but less significant. The results also indicated that the individual effect of the $\mathrm{MgSO}_{4} \cdot 7 \mathrm{H}_{2} \mathrm{O}$ volume does not affect the absorbance intensity, indicating that all $\mathrm{MgSO}_{4} \cdot 7 \mathrm{H}_{2} \mathrm{O}$ volumes tested were in sufficient excess to promote the

Table 1. Design matrix of the full factorial design $\left(2^{3}\right)$ plus center points

\begin{tabular}{|c|c|c|c|c|c|c|}
\hline \multirow[t]{2}{*}{ Run } & \multicolumn{3}{|c|}{ Un-coded variables levels } & \multicolumn{3}{|c|}{ Coded variables levels } \\
\hline & $\mathrm{MgSO}_{4} \cdot 7 \mathrm{H}_{2} \mathrm{O}^{\mathrm{a}} /(\mathrm{mL})$ & $\mathrm{CA}^{\mathrm{b}} /(\mu \mathrm{L})$ & Heating time/(min) & $\mathrm{MgSO}_{4} \cdot 7 \mathrm{H}_{2} \mathrm{O}^{\mathrm{a}} /(\mathrm{mL})$ & $\mathrm{CA}^{\mathrm{b}}(/(\mu \mathrm{L})$ & Heating time/(min) \\
\hline 1 & 3.00 & 400 & 30 & - & - & - \\
\hline 2 & 5.00 & 400 & 30 & + & - & - \\
\hline 3 & 3.00 & 800 & 30 & - & + & - \\
\hline 4 & 5.00 & 800 & 30 & + & + & - \\
\hline 5 & 3.00 & 400 & 60 & - & - & + \\
\hline 6 & 5.00 & 400 & 60 & + & - & + \\
\hline 7 & 3.00 & 800 & 60 & - & + & + \\
\hline 8 & 5.00 & 800 & 60 & + & + & + \\
\hline 9 & 5.00 & 800 & 60 & + & + & + \\
\hline $10^{\mathrm{c}}$ & 4.00 & 600 & 45 & 0 & 0 & 0 \\
\hline $11^{\mathrm{c}}$ & 4.00 & 600 & 45 & 0 & 0 & 0 \\
\hline
\end{tabular}

${ }^{\mathrm{a}} 60 \%(\mathrm{~m} / \mathrm{v}) ;{ }^{\mathrm{b}} 5 \%(\mathrm{~m} / \mathrm{v}) ;{ }^{\mathrm{c}}$ Center points. 
reaction. Therefore, the $\mathrm{MgSO}_{4} \cdot 7 \mathrm{H}_{2} \mathrm{O}$ volume was fixed at $3.00 \mathrm{~mL}$, correspondent to negative level $(-1)$.

Based on the results obtained in full factorial design, a central composite design (CCD) was outlined in order to obtain the best conditions for the reaction. The studied factors were heating time and $\mathrm{AC}$ volume. This design is especially useful because it provides sufficient factor combinations to fit the full second order polynomial model and this model can be used to approximate almost any smooth surface over a limited domain. CCD consisted of a two-level factorial design $\left(2^{2}\right)$, added with four star points situated at a distance \pm 1.414 from the centre of the design, and three replicates at the centre. ${ }^{22}$ The variables considered and its examined levels (un-coded and coded) and the experimental matrix are given in Table 2.

Table 2. Matrix obtained from the coordinates of the central composite design points

\begin{tabular}{lcccc}
\hline Run & \multicolumn{2}{c}{ Un-coded variables levels } & \multicolumn{2}{c}{ Coded variables levels } \\
AC/ $(\mu \mathrm{L})$ & $\begin{array}{c}\text { Heating } \\
\text { time/(min) }\end{array}$ & $\mathrm{AC} /(\mu \mathrm{L})$ & $\begin{array}{c}\text { Heating } \\
\text { time/(min) }\end{array}$ \\
\hline 1 & 314.5 & 51.5 & -1 & -1 \\
2 & 314.5 & 58.6 & -1 & +1 \\
3 & 385.5 & 51.5 & +1 & -1 \\
4 & 385.5 & 58.6 & +1 & +1 \\
$5^{\mathrm{a}}$ & 350.0 & 55.0 & 0 & 0 \\
$6^{\mathrm{a}}$ & 350.0 & 55.0 & 0 & 0 \\
$7^{\mathrm{a}}$ & 350.0 & 55.0 & 0 & 0 \\
8 & 350.0 & 50.0 & 0 & -1.41 \\
9 & 350.0 & 60.0 & 0 & 1.41 \\
10 & 300.0 & 55.0 & -1.41 & 0 \\
11 & 400.0 & 55.0 & 1.41 & 0 \\
\hline${ }^{2} \mathrm{C}$ & & & &
\end{tabular}

${ }^{\mathrm{a}}$ Center points in triplicate.

Figure 3 represents the three-dimensional graph obtained from experimental data and fitted to the response surface. The quadratic regression model is given by equation:

$\mathrm{z}=-13.836+0.43784 \mathrm{x}-0.003325 \mathrm{x}^{2}+0.01965 \mathrm{y}-$ $0.00002045889 \mathrm{y}^{2}-0.00012915 \mathrm{xy}$

where $\mathrm{z}$ is the response factor corresponding to the absorbance value, $\mathrm{x}$ and $\mathrm{y}$ factors are the CA volume and heating time, respectively.

The calculated regression coefficient $\left(\mathrm{R}^{2}\right)$ was $0.89 \%$, indicating that the obtained equation explains the relationship between the experimental results and the effects of the studied factors.
It can be observed by the surface shape (Figure 3) that the optimal region was found and also that the maximum responses were achieved with $300 \mu \mathrm{L}$ of the $5 \%(\mathrm{~m} / \mathrm{v}) \mathrm{CA}$ and heating time of $60 \mathrm{~min}$.

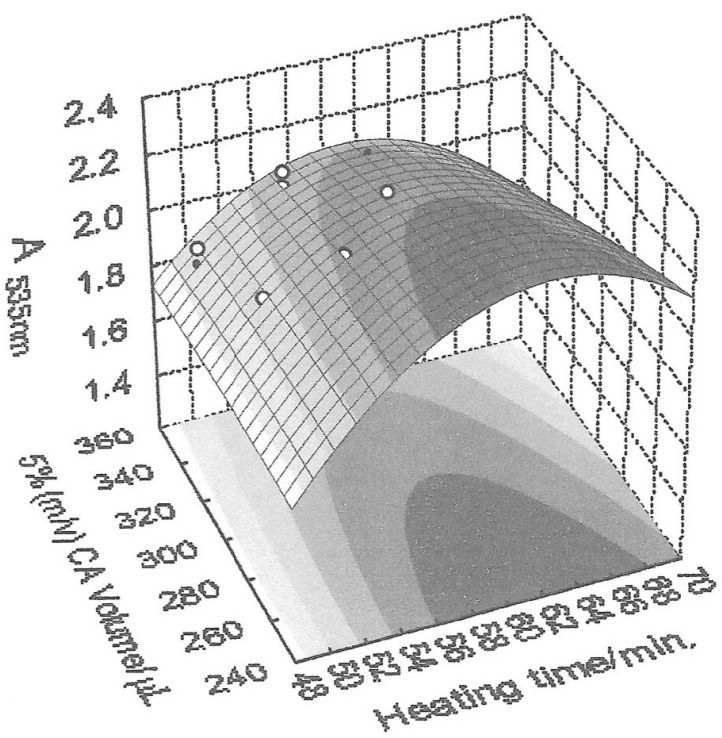

Figure 3. Three-dimensional plot of the optimized surface response of absorbance measurements at variable $5 \%(\mathrm{~m} / \mathrm{v})$ CA volume and heating time.

\section{Analytical data}

The developed analytical method was validated by evaluating linear dynamic range, precision, limit of detection (LOD) and limit of quantification (LOQ).

Under the optimized experimental conditions, the linear calibration curve was constructed from 3.00 up to $11.0 \mathrm{mg} \mathrm{L}^{-1}$ formaldehyde standard solutions. The least square treatment of calibration data $(n=7)$ yielded the regression equation:

$\mathrm{A}=-0.157\left( \pm 1.33 \times 10^{-2}\right)+8.84 \times 10^{-2}\left( \pm 1.17 \times 10^{-3}\right) C$

The correlation coefficient was 0.999 , indicating the excellent linearity of the calibration curve at $95 \%$ confidence level.

Assay precision was defined by determining intraday and interday variation, expressed as relative standard deviation (RSD). The interday variation was evaluated over 5 days. The intraday precision and interday precision were studied for 6 replicate analyses of $7.00 \mathrm{mg} \mathrm{L}^{-1}$ formaldehyde standard solution. The coefficients of variation were 1.1 and $1.72 \%$, respectively. The LOD $\left(3 \times \mathrm{SD}^{\text {blank/slope of }}\right.$ analytical curve $)$ and LOQ $\left(10 \times \mathrm{SD}^{\text {blank}} /\right.$ slope of analytical curve) were $0.30 \mathrm{mg} \mathrm{L}^{-1}$ and $1.00 \mathrm{mg} \mathrm{L}^{-1}$, respectively. ${ }^{23}$ 
Compared with widely accepted NIOSH procedures ${ }^{11,12}$ for the formaldehyde assay the proposed method shows relatively higher detection limit. Nevertheless, considering the quantities of formaldehyde present in the samples studied the proposed method is sufficiently sensitive to permit the determination of this analyte in commercial disinfectants and deffrizing hair products.

\section{Interference study}

The possible interference of compounds commonly present in commercial formulations of disinfectants and defrizzing products was carefully investigated. It was found that sodium dodecylbenzenesulfonate, other aldehydes, ethanol, and eucalyptus essence do not interfere with the determination of formaldehyde by the proposed method.

\section{Analytical application}

The applicability of the proposed method for the determination of formaldehyde in commercial preparations was examined by analyzing formaldehyde in disinfectants and defrizzing products to hair smoothing with illicit addition of formaldehyde. The results of the proposed method were statistically ${ }^{24}$ compared with those obtained by the official procedure ${ }^{13}$ and are summarized in Table 3.

Table 3. Determination of formaldehyde in samples

\begin{tabular}{lcccc}
\hline Samples & \multicolumn{2}{c}{ Proposed method } & \multicolumn{2}{c}{ Official method $^{13}$} \\
& Found $^{\mathrm{c}}$ & $t_{(2.78)}{ }^{\mathrm{d}}$ & $F_{(19.00)}{ }^{\mathrm{d}}$ & Found $^{\mathrm{c}}$ \\
\hline $\mathrm{A}^{\mathrm{a}}$ & $8.16 \pm 0.10$ & 1.21 & 1.00 & $8.06 \pm 0.10$ \\
$\mathrm{~B}^{\mathrm{a}}$ & $8.32 \pm 0.07$ & 0.11 & 1.00 & $8.31 \pm 0.08$ \\
$\mathrm{C}^{\mathrm{a}}$ & $4.67 \pm 0.02$ & 0.50 & 4.00 & $4.66 \pm 0.01$ \\
$\mathrm{D}^{\mathrm{b}}$ & $36.4 \pm 0.7$ & 1.30 & 1.84 & $35.8 \pm 0.5$ \\
$\mathrm{E}^{\mathrm{b}}$ & $54.7 \pm 1.3$ & 0.59 & 1.53 & $56.2 \pm 1.6$ \\
\hline
\end{tabular}

${ }^{\mathrm{a} C}$ Concentration values: $\%(\mathrm{~m} / \mathrm{v})$ for disinfectants liquid samples; ${ }^{\mathrm{b}}$ Concentration values: $\%(\mathrm{~m} / \mathrm{m})$ for defrizzing hair samples; ${ }^{\mathrm{c} A v e r a g e ~} \pm$ standard deviation (SD) of three independent analysis; ${ }^{\mathrm{T}} \mathrm{The}$ values between parentheses are the theoretical values of $t$ and $F$ at 95\% confidence level.

In all cases, the calculated $t$ and $F$ values did not exceed the theoretical values at $95 \%$ confidence level, indicating that there is no significant difference between either methods in concerning precision and accuracy in the determination of formaldehyde in commercial preparations.

\section{Conclusions}

The results of the present work provide a significant contribution to a greener analytical methodology without any hazardous substance. The use of strongly acidic media was eliminated and advantageously replaced by magnesium sulphate, which is benign to human and to the environment. The method allows the determination of formaldehyde at low operating costs and shows simplicity, adequate selectivity and requires only standard lab equipment. In addition, the dissociation of the complex in alkaline media regenerates the free cyclo-tetrachromotropylene, which has potentialities for application as extractor of metal ions. ${ }^{20}$

In Brazil, green analytical chemistry is in its initial stage of development but there is a trend towards fast and consistent growth. Soon, analytical methods showing high performance but which are not environmental-friendly tend to be unacceptable and this will stimulate the development of cleaner methods. This significantly contributes to develop an essential environmental conscience for the future. This paper is an important step in this direction.

\section{Acknowledgments}

We would like to thank CNPq and FAPESP Agencies (Brazil) for financial support.

\section{References}

1. Budavari, S.; ed. In The Merck Index: An Encyclopedia of Chemicals Drugs and Biologicals, $13^{\text {th }}$ ed., Merck: New Jersey, 2001.

2. Kirk, R. E.; Othmer, D. F.; eds. In Encyclopedia of Chemical Technology, The Interscience Encyclopedia: New York, 1951, vol. 6 .

3. Manahan, S. E.; Environmental Chemistry, $6^{\text {th }}$ ed., Lewis Publishers: Florida, 1994.

4. International Programme on Chemical Safety, Formaldehyde Health and Safety Guide n. 57, World Health Organization: Geneva, 1991.

5. Thyssen, J. P.; Johansen, J. D.; Menne, T.; Contact Dermatitis 2007, 56, 185.

6. http://www.anvisa.gov.br/cosmeticos/alisantes/escova_ progressiva.htm, accessed in July 2006.

7. Li, J.; Dasgupta, P. K.; Luke, W.; Anal. Chim. Acta 2005, 51, 531.

8. Pickard, A. D.; Clark, E. R.; Talanta 1984, 31, 763.

9. West, P. W.; Sen, B.; Fresenius Z. Anal. Chem. 1956, 153, 177.

10. Sawicki, E.; Hauser, T. R.; McPherson, S.; Anal. Chem. 1962, $34,1460$.

11. National Institute for Occupational Safety and Health, NIOSH Manual of Analytical Methods (NMAN), $2^{\text {nd }}$ ed., US Department of Health, Education and Welfare: US, 1977, vol. 1. 
12. National Institute for Occupational Safety and Health, NIOSH Manual of Analytical Methods (NMAN), $4^{\text {th }}$ ed., US Department of Health, Education and Welfare: US, 1994, method 3500(2) formaldehyde.

13. Georghiou, P. E.; Ho, C. K.; Can. J. Chem. 1989, 67, 871.

14. Fagnani, E.; Melios, C. B.; Pezza, L.; Pezza, H. R.; Talanta 2003, 60, 171.

15. Gigante, A. C.; Gotardo, M. A.; Tognolli, J. O.; Pezza, L.; Pezza, H. R.; Microchem. J. 2004, 77, 47.

16. Anastas, P. T.; Warner, J. C.; Green Chemistry: Theory and Practice, Oxford University Press: New York, 1998.

17. Keith, L. H.; Gron, L.U.; Young, J. L.; Chem. Rev. 2007, 107, 2695.

18. Anastas, P. T.; Crit. Rev. Anal. Chem. 1999, 29, 167.

19. Poh, B.-L.; Lim, C. S.; Khoo, K. S.; Tetrahedron Lett., 1989, $30,1005$.
20. Poh, B.-L.; Lim, C. S.; Khoo, K. S.; Tetrahedron 1990, 46, 4379.

21. Toutianoush, A.; Schnepf, J.; El Hashani, A.; Tieke, B.; Adv. Funct. Mater. 2005, 15, 700.

22. Montgomery, D. C.; Myers, R. H.; Response Surface Methodology: Process and Product Optimization Using Designed Experiments, $2^{\text {nd }}$ ed., Wiley: New York, 2002.

23. Long, G. L.; Winefordner, J. D.; Anal. Chem. 1983, 55, $712 \mathrm{~A}$.

24. Miller, J. C.; Miller, J. N.; Statistics for Analytical Chemistry, Ellis Horwood Limited: London, 1992.

Received: April 25, 2008

Web Release Date: September 29, 2008

FAPESP helped in meeting the publication costs of this article. 